Cellular Physiology
and Biochemistry and Biochemistry Published online: May 03,2016

Accepted: March 27, 2016

This aricle is licensed under the $\mathrm{Cr}$ This article is licensed under the Creative Commons Attribution-NonCommercial-NoDerivatives 4.0 Interna-
tional License (CC BY-NC-ND) (http://www.karger.com/Services/OpenAccessLicense). Usage and distribution for commercial purposes as well as any distribution of modified material requires written permission.

Review

\title{
Somatic Mutation Theory - Why it's Wrong for Most Cancers
}

\author{
Björn L.D.M. Brüchera-d Ijaz S. Jamalla,bee \\ aTheodor-Billroth-Academy ${ }^{\circledR}$, Munich, Germany - Sacramento, California, USA; bINCORE, International \\ Consortium of Research Excellence of the Theodor-Billroth-Academy ${ }^{\circledR}$, Munich, Germany - \\ Sacramento, California, USA; 'Bon Secours Cancer Institute, Richmond, VA, USA; dDep. Of Surgery, Carl- \\ Thiem-Klinikum, Cottbus, Germany; eRisk-Based Decisions Inc., Sacramento, CA, USA
}

\section{Key Words}

Carcinogenesis - Somatic mutation theory - Microenvironment - Cell communication • Signaling • Inflammation • Chronic inflammation - Fibrosis • Cell transition • Precancerous niche

\begin{abstract}
Hysteron proteron reverses both temporal and logical order and this syllogism occurs in carcinogenesis and the somatic mutation theory (SMT): the first (somatic mutation) occurs only after the second (onset of cancer) and, therefore, observed somatic mutations in most cancers appear well after the early cues of carcinogenesis are in place. It is no accident that mutations are increasingly being questioned as the causal event in the origin of the vast majority of cancers as clinical data show little support for this theory when compared against the metrics of patient outcomes. Ever since the discovery of the double helical structure of DNA, virtually all chronic diseases came to be viewed as causally linked to one degree or another to mutations, even though we now know that genes are not simply blueprints, but rather an assemblage of alphabets that can, under non-genetic influences, be used to assemble a business letter or a work of Shakespearean literature. A minority of all cancers is indeed caused by mutations but the SMT has been applied to all cancers, and even to chemical carcinogenesis, in the absence of hard evidence of causality. Herein, we review the 100 year story of SMT and aspects that show why genes are not just blueprints, how radiation and mutation are associated in a more nuanced view, the proposed risk of cancer and bad luck, and the in vitro and in vivo evidence for a new cancer paradigm. This paradigm is scientifically applicable for the majority of nonheritable cancers and consists of a six-step sequence for the origin of cancer. This new cancer paradigm proclaims that somatic mutations are epiphenomena or later events occurring after carcinogenesis is already underway. This serves not just as a plausible alternative to SMT and explains the origin of the majority of cancers, but also provides opportunities for early interventions and prevention of the onset of cancer as a disease.
\end{abstract}




\section{Cellular Physiology Cell Physiol Biochem 2016;38:1663-1680 \\ and Biochemistry Published online: May 03, $2016 \quad \begin{aligned} & \text { DOI: 10.1159/000443106 } \\ & \begin{array}{l}\text { (c) } 2016 \text { The Author(s). Published by S. Karger AG, Basel } \\ \text { www.karger.com/cpb }\end{array}\end{aligned}$ \\ Brücher/Jamall: Hysteron and Proteron of the Somatic Mutation Theory}

\section{Introduction}

The hysteron proteron of the somatic mutation theory (SMT) appears because the first event (mutations), in fact occur later in the process, i.e., only after the cell has been transformed from a normal cell to a cancer cell via a process termed carcinogenesis. Mutations have increasingly been perceived as the causal event in the origin of the vast majority of cancers even as clinical data show little support for this theory when compared against the metrics of patient outcomes. Another challenge is the lack of reproducibility [1] as less than $20 \%$ of so-called highly ranked 'landmark' papers have been irreproducible [2]. Despite methodological issues, this seems to be a multifactorial omission insofar as original references are increasingly not read and/or cited with a lack of critical analysis resulting in the dominance of erroneous conclusions from research data [3] as has been pointed out recently [4]. This is especially true for results obtained from studies in cell lines that do not automatically reflect the reality of tumor biology as, for example, shown in ovarian cancer cell lines [5]. Although many papers investigated DNA, microRNA, epigenetics and proteomics had been published, there is 'no evidence whether this DNA originates from dying "normal" cells or from cancer cells or from both [4].

There is little doubt that the knowledge of mutations and genetics have brought about a deeper understanding of biology, and of cancer biology in particular. However, an important distinction lies in whether mutations that are observed in tumor samples have been consistently misinterpreted as being the cause of the underlying malignancy. Hereditary cancers occur in some $10 \%$ of all cancers and genetically triggered primary cancers represent some $8 \%$ of breast and ovarian cancers, which are causally linked to genetic changes such as breast cancer 1, early onset (BRCA1) or breast cancer 2, early onset (BRCA2) mutations; the corresponding figure for gastric cancer is less than $1 \%$, for colorectal cancers it is somewhere between 3 and $5 \%$, and infection-associated cancers are estimated to represent some $15 \%$ of all cancers [6-8]. Even these estimates seem misleading since no one knows why this ratio is about $60 \%$ in gastric cancers with Helicobacter pylori (H. pylori) infection and as high as $80 \%$ in liver cancers with chronic Hepatitis B or C viruses [9]. Therefore, broadly speaking about $80 \%$ of cancers are referred to as being 'sporadic', meaning their cause remains unknown.

It should come as no surprise, therefore, that somatic mutations are questioned as representing "the" cause for the majority of cancers $[10,11]$ and it should be noted that some cancers are not associated with any mutations whatsoever $[12,13]$. De novo mutations in germline cells can be associated with "...rare and common forms of neurodevelopmental diseases, including intellectual disability, autism and schizophrenia" [14], and do not affect the discussion of the somatic mutation theory and carcinogenesis. Otherwise "hybrid viraltransposon systems" may serve as a mechanistic explanation for cancer genomes in higher eukaryotes which are not accessible to germline transgenesis by insertional mutagenesis [15].

The SMT follows other well-worn theories in medicine that, upon closer scrutiny were found to be associated with, but not causally related to, the disease in question. Many of these paradigms occurred from the incorrect interpretations of clinical observations resulting in ineffective clinical practice guidelines [16]. The missing explanation for some $80 \%$ of sporadic cancers was recently proposed as a hypothesis which considered biochemical and physiological processes, communication between cells and cell-cell signaling [17, 18]. A more nuanced view on the SMT and carcinogenesis, why genes are not just blueprints, radiationinduced mutations, the recent paper on why cancer may be a result of just 'bad luck' and in vitro and in vivo evidence justifying the questioning of the SMT are reviewed here.

\section{Somatic mutation theory}

The basis for the SMT hypothesis originated in 1914 when Theodor Boveri postulated that a combination of chromosomal defects could result in cancer [19]. This was followed by the 


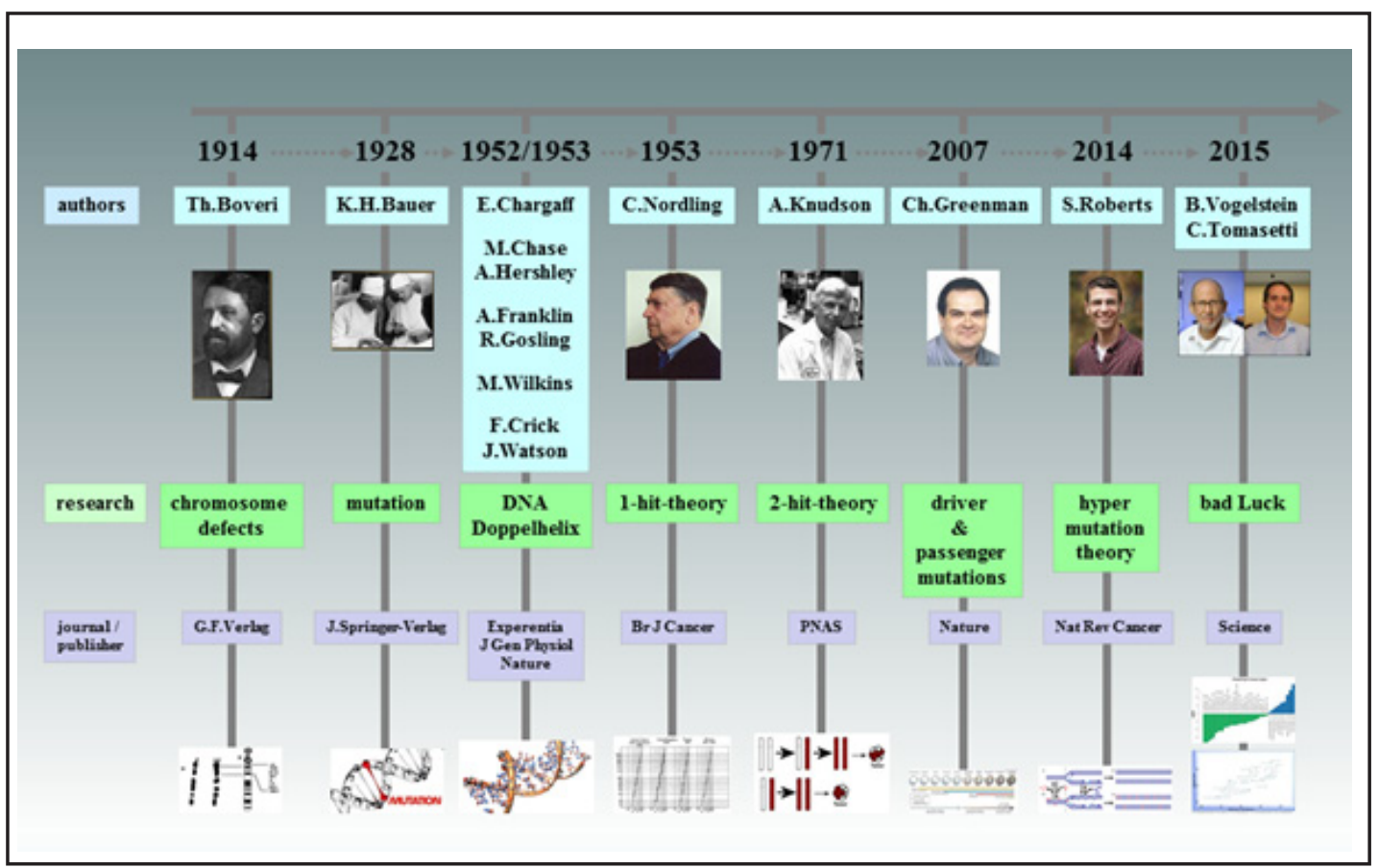

Fig. 1. 100 years somatic mutation theory.

proposal by Karl-Heinrich Bauer that mutations could cause cancer [20]. A milestone during the 1950s was the discovery of the DNA double helix and the genetic information revolution [21]. The noble laureate paper by Watson and Crick [22] was a "theoretical conversation.... with.....little experimental activity" [23] which was based on findings from Erwin Chargaff [24], Alfred Hershley and Martha Chase [25] and the X-ray diffraction study of DNA by Rosalyn Franklin and Raymon Gosling [26]. This led to the discovery of the polymerase chain reaction (PCR) in 1955 by Kleppe and Moulineux and its important modification by Mullis in 1983 $[27,28]$ - a clear revolution of biology and science [29]. However, it was the Finnish architect and urban planner, Carl O. Nordling, who worked through the age-specific cancer mortalities from statistic reports from the USA, UK, France and Norway and suggested that a number of mutated genes could cause cancerous cells to form cancer [30]. Ashley stated in 1969 that cancer may be the result of about 3 to 7 mutations [31]. Based on 48 cases of retinoblastoma, Alfred Knudson modified this mutational theory by proposing that a cell would need just one hit (mutation) and that could result in the mutated cell, by cloning, form a tumor [32]. It is noteworthy that Carl 0. Nordling was even not cited. Later, the 1-hit theory was deemed to be too simplistic and was changed into a 2-hit theory in that a person who inherits a mutant allele must experience a second somatic mutation to initiate carcinogenesis. Some 25 years ago scientists reminded us that mutational changes in general would be insufficient to cause cancer and repeated Ashley's suggestion that at least 4 or 5 mutations might be necessary for such a 'cancer-initiating hit' (CIH) [33].

Even today, some 60 years after Carl 0 . Nordling's hypothesis, there are on-going attempts to force-fit the SMT hypothesis by proposing that three mutations are required to cause lung or colorectal cancer [34] and even postulate that cancer might require a 'hyper-mutation' event [35]. Large-scale sequencing studies have revealed that an even greater number of mutations might be necessary for causing the disease we call "cancer" [36]. Myelodysplastic syndrome (MDS) is used as a prime example of the veracity of the SMT by its proponents but we have learned that risk stratification is needed and that the evolution of risk for leukemia is "...less than $10 \%$ at 15 years for patients with low-risk MDS compared with more than $50 \%$ at 1 year for those with high-risk disease" [37]. Further acute lymphoblastic leukemia (ALL) is thought of as being caused by genetic factors, such as mutations or polymorphisms and environmental exposures; a minority of ALL in children was associated with polymorphisms 


\section{Cellular Physiology Cell Physiol Biochem 2016;38:1663-1680 \\ \begin{tabular}{c|c|c|} 
DOI: 10.1159/000443106 & O 2016 The Author(s). Published by S. Karger AG, Basel \\
www.karger.com/cpb
\end{tabular} \\ Brücher/Jamall: Hysteron and Proteron of the Somatic Mutation Theory}

of rs17251221, rs4946936 or rs6214 and rs6218 in the 3'UTR of insulin-like growth factor 1 (IGF1) [38-40]. Recently it was shown, that ALL cases are not inherited. In vivo genetic evidence uncovered the causal role of infection exposure in acute lymphoblastic B-cell leukemia (B-cell ALL) as B-precursor acute lymphoblastic leukemia was only initiated if Pax5- inherited mice were exposed to common pathogenic stimuli. Furthermore, mutations of Janus-activated kinase 3 (JAK-3) occur after carcinogenesis is already underway [41]. This evidence supports the view that somatic mutations are epiphenomena and/or postcarcinogenesis events that clonally propagate cancer cells $[17,18]$. Given that little by way of patient outcomes has emerged from the SMT, proponents have in recent years added the concept of 'driver' and 'passenger' mutations [42] in addition to the "hyper-mutation" theory [35] to patch over the weak links in the original SMT.

Cancer is not just one aberrant cell and one disease - cancer is a collection of more than 100 diseases with some traits in common [43]. Only a few cases have been associated with one important signalling pathway (e.g., Bcr-Abl tyrosine kinase in chronic myelogenous leukaemia, CML), which has allowed for the deployment of targeted therapy [44]. However, those same targeted therapeutic approaches are subverted over time as resistance develops rendering the treatment less effective and occasionally completely ineffective. A potential way of overcoming resistance against the tyrosine kinase inhibitor, gefitinib, has been recently shown to be effective in vitro by the use of Melatonin ( $\mathrm{N}$-acetyl-5-methoxytryptamine) [45].

An adult human contains trillions of cells of more than 200 types [46]. The one cell that can ultimately create every other type of cell in the body is enshrined in the fertilized ovum. It is known that normal cells can acquire mostly harmless mutations in the course of development from a single fertilized egg to an adult mammal. In fact, the term, 'postzygotic mosaicism' was coined as a unifying term for all DNA changes acquired during life from single base pair mutations to aberrations at the chromosomal level [47]. It was further demonstrated that the post-zygotic genome is dynamic and that post-zygotic mutations represent a hitherto underestimated source of variation responsible for the development of human phenotypes that are not heritable and which cannot explain 'the 'missing heritability' [47]. Forsberg et al., recently suggested that the "weight should shift to the noninherited component which, until now, has routinely been thought of as synonymous with environmental factors" [47].

Importantly, a detailed analysis of 31,717 cancer cases and 26,136 cancer-free controls from 13 genome-wide association studies [48] revealed that "the vast majority, if not all, of aberrations that were observed in the cancer-affected cohort were also seen in cancer-free subjects, although at lower frequency" [47]. Thus, the notion that somatic mutations are necessarily harmful and can lead to cancer is not borne out by this study and further affirms the hypothesis that mutations observed in cancers are not the triggering event but more likely a means for the clonal replication of already transformed cancer cells.

One would expect scientists to reevaluate the original paradigm given its inability to show appreciable clinical benefits over the past several decades. Taken together, the small percentage rates of proven somatic mutations which are indeed causative for a minority of hereditary cancers with the misinterpretation of higher rates of somatic mutations in more advanced stages of cancer, the extrapolation to most cancers from this dataset has confounded cancer biology and carcinogenesis resulting in a conflation of cancer biology that appears unwarranted. It seems logical that somatic mutations are epiphenomena and/ or post-carcinogenesis events $[17,18]$.

\section{Genes are not blueprints}

Ever since Watson and Crick [22], many chronic diseases were thought reflexively to be caused by mutations even though we know that genes are an assemblage of alphabets that can, under non-genetic influence, be used to assemble a wide variety of proteins [4951]. Since no-one still speaks, hears, or even understands the molecular words, sentences, 


\section{Cellular Physiology Cell Physiol Biochem 2016;38:1663-1680

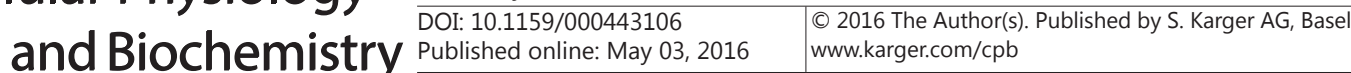 \\ Brücher/Jamall: Hysteron and Proteron of the Somatic Mutation Theory}

or language of genetic information - they result in silent insight [52]. Further, genes are not just blueprints as there is not only an inside-to-outside communication but also an outsideto-inside communication [4]. About $98 \%$ of the total human genome consists of non-coding DNA implying that only some 1-2 \% of the total human DNA has been investigated with regard to its functionality. Even mobile DNA represents more than $40 \%$ of the total genome.

Recently, scientists searched for DNA mutations in 800 cancer patients (some 200 different cancer types) and compared the tumor DNA with the DNA of healthy cells of the same patients [53]. They reported that mutations found in cancer patients were correctly interpreted in the abstract as associated with the different cancer types [53] yet the results were misinterpreted in media interviews as though the authors had concluded that such observed mutations actually caused the observed cancers [54].

Long non-coding RNAs (lncRNAs), including their mutations, have been associated with cancer. As IncRNAs mediate repressor occlusion which include cyclooxygenase-2 (=Prostaglandin G/H synthetase 2, =COX-2), IncRNAs and PACER have been suggested as new targets for COX-2-modulation in inflammation and cancer [55]. However, IncRNAs and the proximity of spatial alleles are necessary for regulating genes [56] and the complexity of physiological homoeostasis and pathophysiology by multiple cellular processes regulating gene function(s) remains incompletely understood. Even mitochondrial DNA transfers between cells are a common physiological process for overcoming DNA damage rather than a pathological event [57]. Furthermore, there is growing evidence that knowledge of the genetic architecture is necessary to elucidate the role of genes which may act differently under different conditions [58]. Sea urchins are echinoderms which originated some 540 million years ago and it was shown by the Sea Urchin Genome Sequencing Project (SUGSP) Consortium that this species has genes for sensory proteins that are involved in vision and hearing in humans although the sea urchin itself has no eyes or ears [59]. Even the apolipoprotein B mRNA-editing enzyme's catalytic polypeptide 3 (APOBEC3) can mutate antibodies by an as yet unidentified mechanism [60].

Measurements of mutagenesis of cells grown in culture yield values of approximately $2 \times 10^{-10}$ single base substitutions/nucleotide/cell division or $1 \times 10^{-7}$ mutations/gene/ cell division; an even lower number has been demonstrated in stem cells in culture [61, 62]. By comparison, the magnitude of DNA damage that occurs routinely during normal cellular processes is enormous. It has been estimated that approximately $10^{4}$ depurinated sites are generated per cell per day and an even larger number of alterations result from reactive oxygen species (ROS) $[63,64]$. Even if one were to assume that cancer arose in a single stem cell, then the spontaneous mutation rate would only be adequate to account for less than one mutation per tumor which led some to propose the hypothesis of a "mutator phenotype", wherein many more mutations may occur through the induction of genetic instability, a hypothesis not yet proven [65]. Investigations using retroviral insertion of mutagens in mice have shown that more than 2,000 genes must be mutated to contribute to cancer development [66]. This illustrates the wide variability in somatic mutations and the discrepancy between mutations required to cause cancer versus the large numbers of mutations that occur physiologically and which do not result in cancers. Aging has long been believed to be a major factor for the accumulation of somatic mutations resulting in a higher incidence of cancers as the animals ages but even this concept is now being questioned as the finite lifespan of hematopoietic stem cells (HSCs), rather than mutations, may lead to hematopoietic clonal evolution at extreme ages [67].

Moreover, signaling between hematopoietic stem and hematopoietic stem progenitor cells (HSPC) are different phenomena as was shown recently: nuclear factor kappa-lightchain-enhancer of activated B cells (NF- $\mathrm{kB}$ ) signaling is the molecular component underlying the observed differences between HSPC and PBL [68]. NF- $\kappa B$ activation has been reviewed $[17,18]$ and shown to be activated by stromal cell-related cytokines of inflammation such as tumor necrosis factor alpha (TNF- $\alpha$ ) [69]. It has also been shown that ROS activate NF$\kappa \mathrm{B}$ and this decreases tumor suppressor genes and increases oncogenes $[17,18,70]$ with C-X-C chemokine receptor type 4 (CXCR4) expression independent of stromal cell-derived 
factor 1 (SDF-1; synonym CXCL12) [71]. However, to date the clinical benefit of antioxidants in the prevention or treatment of cancers remains unproven. Other oncogenes, such as the Kirsten rat sarcoma viral oncogene (KRAS), are thought to be linked to carcinogenesis in cells after being implanted in immune-deficient mice [72]; It is presently not understood why KRAS is not $100 \%$ effective in mouse models [reviewed in 4]. One aspect could be that this is influenced by other genes, such as the Wilms' tumor gene (WT1), with its downstream target (cMYC) investigated in non-small cell lung cancer (NSCLC) [73]; however, WT1 alone has at leat some 24 isoforms.

\section{Radiation - Mutation}

Exposure to ionizing radiation causes cancer and this was seen early on as lending credence to the SMT since radiation was known to cause DNA damage. However, the different leukemia incidences with different dose-response curves for Hiroshima and Nagasaki after the two different types of A-bombs were dropped provides a different explanation. In Hiroshima, a linear dose-response curve was observed in leukemia incidence as the ionizing radiation in the bomb dropped there was of a high linear energy transfer (LET) type which caused double strand breaks in DNA such that the repair enzymes had no template to use to repair the damaged DNA [74]. In contrast, the bomb dropped over Nagasaki released low-LET radiation which primarily caused single-strand DNA damage and the repair enzymes were able to use the intact strand as a template to repair the DNA damage. Thus, the dose-response curve for leukemia in Nagasaki was S-shaped (as it is true for most noncarcinogenic chemicals and pharmaceuticals) [75]. If we apply this information on somatic mutations to radiation-induced cancers, only agents that cause double-strand DNA breakage become clinically relevant, unless one has defective DNA repair enzymes as in children with the autosomal recessive condition known as Xeroderma pigmentosum [76, 77]. In most non-hereditary cancers, the somatic mutations appear only after a normal cell becomes a cancerous cell and this allows the cancer cell to multiply in a clonal fashion. Neither the 1-hit nor the 2-hit nor the hyper-mutator phenotype theories account for the role of the DNA repair systems nor do they account for epigenetic modifications that protect against an even higher incidence of cancers than observed.

\section{Cancer and bad luck}

The most recent version of the SMT proposed that one's odds of getting cancer was a statistical event attributed to 'bad luck' through the accumulation of "enough" mutations to cause cancer [78]. If we remind ourselves about the percentages of cancers unquestionably attributed to mutations discussed above (about $5 \%$ of all cancers), we recognize that only a minority of cancers are triggered by mutations [6-8]. The "bad luck" thesis lacks, as the basis for the authors' stochastic model, several facts that appear to have been papered over. These include, 1) the theory that mutations cause cancer, and 2) that the risk of mutations is relatively constant for a given number of cell divisions. As pointed out above, the SMT is valid for some $5 \%$ of hereditary cancers, and from this alone it is clear that this model with its calculations and conclusions cannot be applied to the majority of non-hereditary cancers. Therefore, mathematically, the bad luck paper presents an untenable model as it can only apply to a small fraction of all cancers and confounds cancer biology with regard to its inapplicability to the vast majority of cancers.

\section{Questioning the dogma}

Recently the dogma of the SMT was deconstructed and the debate of the origin of cancer reignited by a new more plausible hypothesis for the majority of cancers by incorporating findings from both the plant and animal kingdoms, and by including clinical data to spell 


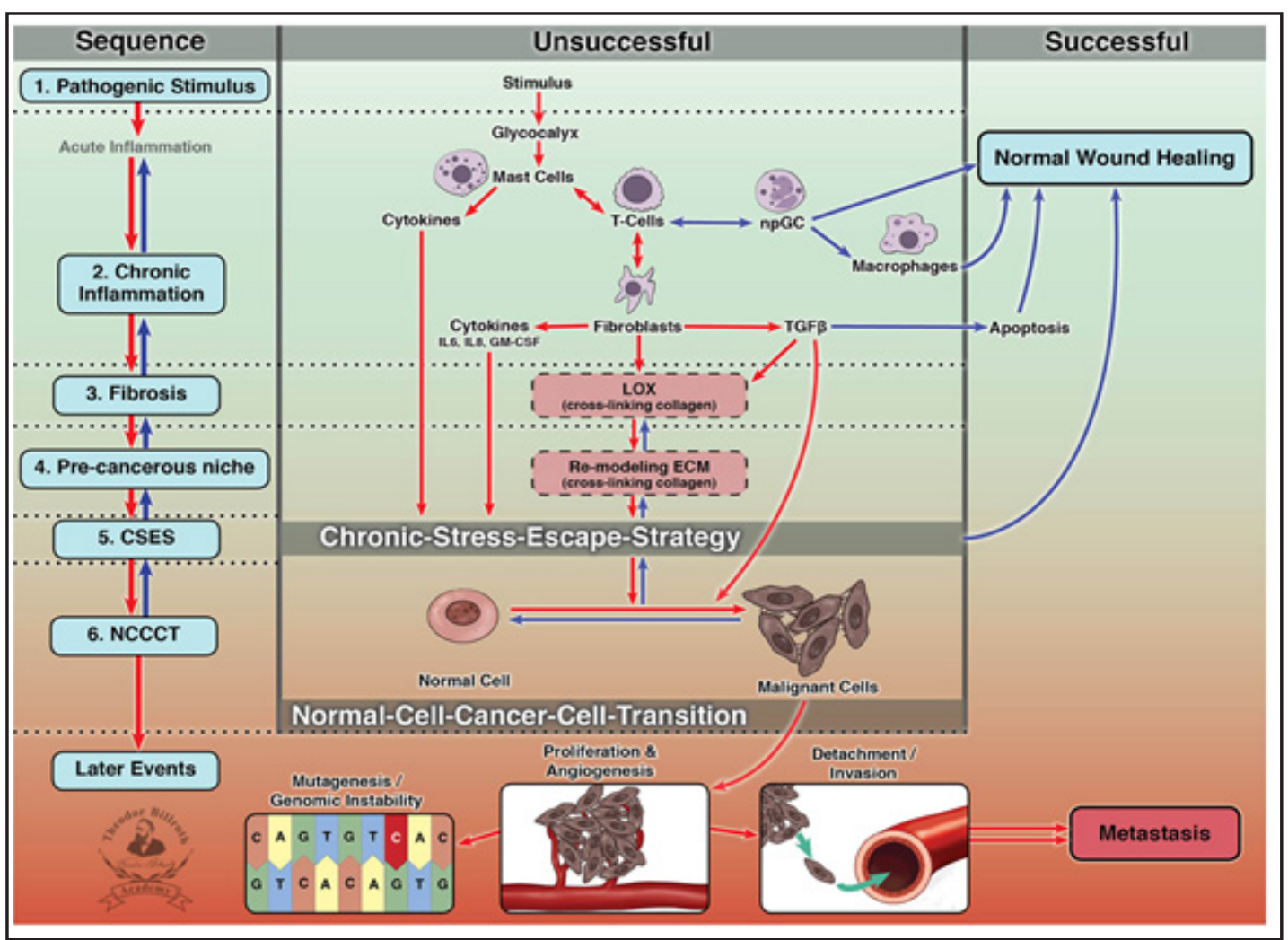

Fig. 2. Multistep carcinogenesis sequences- Epistemology of the origin of cancer [modified according to 17].

out that the following six steps are necessary for a normal cell to become a cancer cell: (1) a pathogenic stimulus (biological or chemical) followed by (2) chronic inflammation, from which develops (3) fibrosis with associated changes in the cellular microenvironment. From these changes a (4) pre-cancerous niche develops which triggers the deployment of (5) a chronic stress escape strategy, and when this fails to resolve, (6) the change of a normal cell to a cancer cell occurs $[17,18]$.

\section{In vitro and in vivo evidence}

The association of human papilloma virus (HPV) as the pathogenic stimulus for inducing cancer of the cervix was discovered in 1983 and by 1999 had been shown to cause nearly all cervical cancers. Human papilloma virus type 16 (HPV16) was initially reported in 11 out of 18 cancer patients in samples from Kenya and Brazil, and in vulva and penile cancer biopsy samples, but only rarely in condylomata accuminata (2/33) [79]. In 1986, cases of condylomatous dysplasia with severe stromal inflammation were negative for HPV more frequently than those with mild stromal inflammation [80]. This was subsequently discussed as an explanation for spontaneous regression. In such cases a T-cell phenotype linked inflammation was observed. Moreover, this investigation revealed that T-cell mediated immune reaction against cells, and not the HPV antigen, induced a systemic spontaneous regression of numerous flat warts in humans before cancer could develop. In 1999, HPV was reported in $93 \%$ of invasive cervical cancers [81]. Today we know that about $45 \%$ of women in the USA between the ages of 20 and 24 years are HPV-positive, an infection known to induce sub-clinical inflammation [82] and such sub-clinical inflammation was also reported in HPV-associated middle ear carcinoma [83] and in penile carcinomas likely by activation of pro-inflammatory cytokines [84, 85]. Recently, HPV was associated with colorectal cancer [86, 87], breast cancer [88] and with esophageal squamous cell carcinoma (ESCC) [89].

\section{KARGER}




\section{Cellular Physiology Cell Physiol Biochem 2016;38:1663-1680 \\ \begin{tabular}{ll|l} 
and BiOChemistry & $\begin{array}{l}\text { DOI: 10.1159/000443106 } \\
\text { Published online: May 03, } 2016\end{array}$ & $\begin{array}{l}\text { C } 2016 \text { The Author(s). Published by S. Karger AG, Basel } \\
\text { www.karger.com/cpb }\end{array}$
\end{tabular} \\ Brücher/Jamall: Hysteron and Proteron of the Somatic Mutation Theory}

Chronic inflammation is an important step in the recently proposed six-step sequence to explain carcinogenesis anew $[17,18]$. The continuous activation of tumor growth factorbeta (TGF- $\beta$ ) activates TGF- $\beta$-activated kinase 1 (TAK1/MEK)-mediated Akt resulting in persistent NF- $\mathrm{KB}$ activation [90] and, which in turn, induces cell proliferation. In 2008, it was shown that matrix metalloproteinase-7 [MMP7; synonym: pump-1 protease (PUMP1, uterine metalloproteinase or Matrilysn] is overexpressed in gastric pre- cancerous and cancerous tissue and that Helicobacter cytotoxin-associated gene (+) selectively increases MMP-7 both in vitro and in vivo [91]. Recently, the same group showed that MMP-7 knockdown mice showed less MMP-7 and increased H.pylori-induced gastric inflammation [92]. All knockdown mice showed increased gastric inflammation and the decreased MMP-7 levels were associated with increased M1 macrophage (a source of inflammation) markers. This was then scrutinized by transfection of H.pylori strain, PMSS1. The authors reported that both hyperplasia and dysplasia were increased in these knockdown mice.

Matrix metalloproteinases (MMPs) are zinc-dependent endopeptidases that regulate tumor suppression [93]. Several MMPs such as MMP-1, MMP-2, MMP-7 MMP-9, MMP-12 and MMP-14 interacts with the extra cellular matrix (ECM) enabling tumor invasion [94]. TGF- $\beta$ was found to be a potent inducer of MMP-2 and MMP-9 expression in a Smad3- and Smad4dependent manner [95] as well as the invasive phenotype in MDA-MB-231 cells, which was associated with TGF- $\beta /$ Smad and TGF- $\beta$ /ERK signaling [96].

The expression profiles of some MMPs have been correlated with poor clinical prognosis for several human tumors [97]. Historically, MMPs are thought to exert both pro-invasive and pro-metastatic activities by affecting remodeling of ECM [98]. ADAM-10 is a disintegrin (functions as an inhibitor of Integrin-dependent cell adhesion) and a metalloproteinase domain-containing protein 10. Under certain experimental conditions ADAM-10 can be inhibited [99] and behaves as tissue inhibitor of metalloproteinases-1 (TIMP-1) [100]. Adenovirus mediated TIMP-1 can reduce tumor cell invasion $[101,102]$. MMPs are locally active at cell membranes if they are not inhibited by TIMP [103].

MMP-7was discovered in the uterus by Woessner [104]. MMP-7 breaks down the ECM by degrading casein, fibronectin, or collagen types I, II, IV and V [105]. MMP-7 has the ability to promote lung colonization of chondrosarcomas in vivo [106], was shown to be overexpressed in advanced colorectal polyps with severe dysplasia, and to facilitate their conversion to malignant cells [107]. MMP-7 appears to contribute to tumor aggressiveness as it is overexpressed at the invasion front of the tumor [108]. The expression of MMP-7 is regulated by the Wnt/ $\beta$-catenin pathway and mediated by TGF- $\beta$ [92] which may explain why MMP-7 is up-regulated in H.pylori infections [109]. TGF- $\beta$ stimulates MMP-7 facilitating invasive behavior [103].

TGF- $\beta$ induces MMP-9 production and activity. TGF- $\beta$ mediated amplification of MMP-9 was attenuated by knockdown of a MYC-interacting transcriptional modulator Cited2 (CBP/ p300-interacting transactivators with glutamic acid (E)/aspartic acid (D)-rich C-terminal domain) in a breast cancer cell line (MDA-MB-231 cells) [110]. Further it was shown, that TGF- $\beta$ promotes MMP-9 mediated cancer cell invasion through SNAIL [111]. Thus, amplification of MMP-9 levels was shown to promote the destruction of the ECM and to increase the migration of inflammatory cells [112] while also playing a role in breast cancer invasion and metastasis through the degradation of type IV collagen-rich ECM [113].

Chronic inflammation results in continuous release of TGF- $\beta$ with many consequent effects $[17,18]$. E-cadherin and occludin are repressed by TGF- $\beta$ increasing the adherens junction disassembly [114]. Invasiveness can be decreased by inhibiting TGF $\beta$ receptor type-I [115]. MiR21 is one key regulator of the mesenchymal phenotype transition and is induced by TGF- $\beta$ [116], and increased levels have also been observed early in chronic fibrosis in chronic obstructive pulmonary disease (COPD) patients [117].

Lysyl oxidase (LOX) modulates the ECM and also affects cell migration and growth [118] and LOX-2 is critical to tumor microenvironment (and metastatic niche formation in hepatocellular carcinoma) [119]. Fibrosis is linked to TGF- $\beta$-integrin signaling in cancer [120] and was shown to be reversed by Relaxin and LOX-inhibitor therapy [121]. The pro- 
inflammatory microenvironment reported recently in observations of HPV and colorectal cancer tissues [86], breast cancer [87, 88] and esophageal cancer [89] may lead to a precancerous niche (PCN) $[17,18]$. Furthermore, TGF- $\beta$ induces LOX and MMPs [122], and LOX itself activates phosphoinositide-3 kinase (PI3K) [123]. SNAIL is stabilized by the protein kinase B (AKT) induced phosphorylation of glycogen synthase kinase-3beta (GSK3beta) [124], and this results in an increase of TGF- $\beta$-induced SNAIL [125]. LOX activates the stability and activity of SNAIL [126]. The long isoform p120 dissociates from the membrane and accumulates in the cytoplasm due to TGF $\beta[127,128]$. Taken together, these observations provide a plausible explanation for why the accumulation of p120 in the cytoplasm by chronic TGF- $\beta$ release with its activation of LOX induces remodeling of the ECM forming the $\mathrm{PCN}$, a process that may be seen as the starting point for the chronic-stress escape strategy as recently proposed $[17,18]$.

This serves as a plausible explanation for how chronic inflammation triggers fibrosis resulting in the formation of a PCN $[17,18]$. Evidence why fibrosis, which results from chronic inflammation, is necessary for creating the PCN step comes from studies in the uniquely cancer resistant, long-living mole rat, the Spalax. Fibroblasts in this species suppress the growth of human cancer cells in vitro [129] and decrease the activity of hyaluronan synthase 2 [130]. As proposed earlier $[17,18]$ "...if a species (as Spalax) lives for about 30 years and does not develop cancer, even when exposed to known chemical carcinogens, this suggests that in the absence of the pre-cancerous niche, no cancer cells can gain a foothold ".

The connection between chronic inflammation that is capable of inducing fibrosis and which can then facilitate carcinogenesis is seen in Hepatitis B/C viral infection with consequent hepatocellular carcinoma (HCC) $[17,18,131]$. On the one hand this process seems dependent on a protein which is on the surface of white blood cells, the C-C chemokine receptor type 5 (CCR5 or CD195) [132], while on the other hand, it is dependent on TGF- $\beta$ induced Smad phospho-isoform signaling [131]. Neutrophil granulocytes significantly influence the concentration gradient of chemokines such as the cytokine chemokine (C-X-C motif) ligand 1 (CXCL1). CXCL1 has neutrophil chemoattractant activity, is a potent angiogenic factor, and is expressed by macrophages, neutrophils and epithelial cells [133, 134]. Neutrophil granulocytes also regulate stromal interactions and were associated with worse prognoses in both breast and gastric cancers $[135,136]$.

In 2011, it was suggested, that circulating tumor cells (CTCs) in pulmonary veins during lung cancer surgery could be a prognostic indicator for early recurrence [137]. The same group showed that atrial natriuretic peptide (ANP) downregulates the inflammatory response and has a prophylactic effect on post-operative complications of lung surgery [138140]. ANP, besides being an inhibitor of the renin-angiotensin-aldosterone pathway through specific binding to the guanylyl cyclase-A (GC-A) receptor also has an anti-fibrotic effect $[141,142]$. The authors combined these findings during lung cancer surgery and treated lung cancer patients with "anti-inflammatory and anti-fibrotic" ANP and demonstrated that patients so treated exhibited lower recurrence rates [143].

Liver fluke (Opisthorchis viverrini) was shown to result in cholangiocarcinoma (CCC) in golden hamsters and in humans $[144,145]$. Recently, it was shown, that Opisthorchis viverrini induces inflammation which precedes the CCC [146] lending support to the importance of inflammation in carcinogenesis.

The inhibition of vascular endothelial growth factor (VEGF) by neutralizing antibodies (mcr84) abrogated (1) the chemokine (C-X-C motif) ligand 9 (CXCL9) on mRNA and protein levels and (2) MMP-13 which are necessary for triggering fibrosis [147]. Fibrogenesis and tissue repair along with a resolution of fibrosis are promoted by VEGF which may explain why obesity and dysbiosis are associated with carcinogenesis. These observations along with the known fact that epidermal growth factor receptor (EGFR) induces MMP-7 and MMP-13 resulting in the progression of gastric cancers [148] could serve as an explanation for how the pathways come full circle.

Prostate adenoma as well as prostate inflammation is associated with prostate cancer; recently it was shown that chronic prostate inflammation in a mouse model of bacterial 


\section{Cellular Physiology Cell Physiol Biochem 2016;38:1663-1680 \\ \begin{tabular}{l|l} 
and Biochemistry Published online: May 03, 2016 & $\begin{array}{l}\text { Do 2016 The Author(s). Published by S. Karger AG, Basel } \\
\text { www.karger.com/cpb }\end{array}$
\end{tabular} \\ Brücher/Jamall: Hysteron and Proteron of the Somatic Mutation Theory}

inflammation resulted in increases of MMP-2, MMP-9 and LOX-induced fibrosis [149].

In 2006 it was shown that cell transition to specific cell lineages from adult mesenchymal stem cells was dependent on the matrix used and was facilitated by the use of transcription factors [150]. However, it was more recently shown that this might not be necessary insofar as cell lines growing in a matrix can result in high rates of reversion to stem-like cells and this could mean that pluripotency can be produced by modification of the ECM [151], a finding that remains to be replicated.

The transition from one cellular function to another, as well as the transition of one cell type to another is a routine event as opposed to a rare phenomenon $[17,18]$. It has been shown that an epithelial mesenchymal transition (EMT) in embryogenesis/morphogenesis acts in a direction opposite to that of a mesenchymal-epithelial transition (MET) [152]. Furthermore, EMT can reportedly induce non-cancer stem cells to become cancer stem cells $[153,154]$. It was also shown that chronic lung injury can result into a transition of a normal cell into a cancer cell [155].

AKT is activated through PI3K by TGF $\beta$ [156] resulting in activation of the targets of rapamycin complex 1 (mTORC1) and mTORC2 [157]. The PI3K/TmTORC1 pathway is also essential for cancer-associated inflammation [158]. Further, it was shown, that activation of PI3K/Akt and Erk through TGF- $\beta$ mediated Syk and Src signaling resulted in EMT in human corneal epithelial cells (HCECs) in vitro initiated by Epstein-Barr virus (EBV)-associated keratitis [159]. Hypoxia-induced invasion and migration in cervical cancer cells mediated by the EMT were enhanced by LOX and inhibited by the LOX-inhibitor $\beta$-aminopropionitrile (BAPN) [160]. Sonic hedgehog (Shh) signaling is stimulated by TGF- $\beta$ and regulates fibroblast function [161]. On the other hand, both EMT and Shh signaling are induced by TGF- $\beta$ in bladder cancer [162]. Recently proteome profiling of urine samples from bladder cancer patients associated with Schistosoma haematobium infection [163] revealed further strong evidence of the proposed multi-sequence carcinogenesis process $[17,18]$.

\section{Conclusions}

The incorrect interpretation of data can sometimes appear to be the more parsimonious explanation especially when it has acquired the mantle of a paradigm, as in the case of the SMT. Summa Cancerologica is not hypothetical or ontological. Its syllogism of carcinogenesis needs the consideration of all reasonable perspectives such as whether somatic mutations are later events or epiphenomena occurring at the end of the sequence of events in carcinogenesis. This mutatio praemissarum leads to a reflection of reasoned judgments of correct findings in cancer (mutations within tumors) together with clinical observations (relevance of such mutations to cancer therapy). An overemphasis of the SMT as the sole reason of the origin of carcinogenesis elevated it to the status of a dogma which downplays significant findings of mutations and genetics in different fields of nature, biology and science. However, there is hope that hereditary cancers can be treated in the near future as new technologies make it possible to manipulate proteins packaging DNA to turn on specific gene promoters and enhancers [164]. If this were applicable to the mass of non-hereditary cancers this approach would still be only symptomatic as the genesis of non-hereditary cancers is not caused by somatic mutations though somatic mutations occur within tumors. Focusing on the tumor cell without its origin including the microenvironment won't be enough [165]. The reasoning on the origin of carcinogenesis, including different step-wise sequences, may help unmask mechanisms of the transition of a normal into a cancer cell (cancer genesis) as well as its different primary pathogenic stimulus, which can serve to prevent or retard cancers instead of concentrating on symptomatic strategies or for a cure for all cancers. It is scientifically valid based on in vitro and in vivo genetic findings that carcinogenesis consists of a six-step multi sequence process $[17,18]$. This serves not just as a plausible alternative to the SMT to explain the origin of the majority of cancers, but could also suggest early interventions and thereby prevent the onset of cancer as a disease. 


\begin{tabular}{|c|c|c|}
\hline \multirow{2}{*}{$\begin{array}{l}\text { Cellular Physiology } \\
\text { and Biochemistry }\end{array}$} & \multicolumn{2}{|c|}{ Cell Physiol Biochem 2016;38:1663-1680 } \\
\hline & $\begin{array}{l}\text { DOI: 10.1159/000443106 } \\
\text { Published online: May 03, } 2016\end{array}$ & $\begin{array}{l}\text { O } 2016 \text { The Author(s). Published by S. Karger AG, Basel } \\
\text { www.karger.com/cpb }\end{array}$ \\
\hline
\end{tabular}

\section{Abbreviations}

ALL (acute lymphoblastic leukemia); ANP (atrial natriuretic peptide); APOBEC3B (apolipoprotein B mRA-editing enzyme, catalytic polypeptide-like 3B (= A3B)); Akt (protein kinase B); BAPN ( $\beta$-aminopropionitrile); B-cell ALL (acute lymphoblastic B-cell leukemia); BRCA1 (breast cancer 1, early onset); BRCA2 (breast cancer 2, early onset); CCC (cholangiocarcinoma); CCR5 (C-C chemokine receptor type 5 (=CD195)); CIH (Cancer initiating hit); CML (chronic myelogeneous leukemia); COPD (chronic obstructive pulmonary disease); COX-2 (cyclooxygenase-2 (=Prostaglandin G/H synthetase 2)); CTCs (circulating tumor cells); CxCL1 (chemokine (C-X-C motif) ligand 1); CxCL9 (chemokine (C-X-C motif) ligand 9); CXCR4 (C-X-C chemokine receptor type 4); EBV (Epstein-Barr virus); ECM (extracellular matrix); EMT (epithelial-mesenchymal transition); ESCC (esophageal squamous cell carcinomas); GC-A (guanylyl cyclase-A); GSK3beta (glycogen synthasekinase3 beta); HCC (hepatocellular carcinoma); HCECs (human corneal epithelial cells); HPV (human papilloma virus); HPV16 (human papilloma virus type 16); HSCs (hematopoetic stem cells); IGF1 (insulin-like growth factor 1); IncRNAs (long non-coding RNAs); JAK-3 (Janus-activated kinase); LOX (lysyl oxidase); KRAS (Kirsten rat sarcoma viral oncogene); MET (mesenchymal-epithelial-transition); Melatonin (N-acetyl-5-methoxytryptamine); MMP (matrix metalloproteinase); MMP7 (matrix metalloproteinase-7); NF- $\mathrm{BB}$ (nuclear factor kappa-light-chain-enhancer of activated B cells); PCR (polymerase chain reaction); PCN (pre-cancerous niche); PI3K (Phosphoinositide-3 kinase); ROS (reactive oxygen species); SDF-1 (stromal cell-derived factor 1 (synonym CXCL12) ); Shh (sonic hedgehog); SMT (somatic mutation theory); SUGSP (Sea Urchin Genome Sequencing Project); TAK1 (TGF- $\beta$-activated kinase 1 ); TGF- $\beta$ (tumor growth factor-beta); TIMP-1 (Tissue inhibitor of metalloproteinase); TNF- $\alpha$ (tumor necrosis factor alpha); TORC1 (target of rapamycin complex 1); TORC2 (target of rapamycin complex 2); VEGF (vascular endothelial growth factor).

\section{Acknowledgement}

The manuscript was supported by the Theodor-Billroth-Academy® (TBA®) and INCORE, (International Consortium of Research Excellence) of the (TBA $\left.{ }^{\circledR}\right)$. We gratefully acknowledge the prior discussion at the web group of the Theodor-Billroth-Academy ${ }^{\circledR}$ (TBA®) on LinkedIn as well as on exchange at ResearchGate and the personal exchange with the following distinguished colleagues who stimulated our thinking: Vladimir Matveev, Ray Perkins, Peter Shimon and Jan Voskuil.

\section{Disclosure Statement}

Neither author has a competing interest to disclose.

\section{References}

$1 \quad$ Van Noorden R: Interdisciplinary research by the numbers. Nature 2015;525:306-307.

2 Begley CG, Ellis LM: Drug development: Raise standards for preclinical cancer research. Nature 2012;483:531-533.

3 Neimark J. The dirty little secret in cancer research. 2nd Oct 2014: http://discovermagazine.com/2014/ nov/20-trial-and-error (2014).

4 Brücher BLMD, Li Y, Schnabel P, Daumer M, Wallace TJ, Kube R, Zilberstein B, Steele S, Voskuil JLA, Jamall IS: Genomics, microRNA, Epigenetics, and Proteomics for Future Diagnosis, Treatment and Monitoring Response in Upper GI Cancers. Clin Transl Med 2016; in press.

5 Domcke S, Sinha R, Levine DA, Sander C, Schultz N: Evaluating cell lines as tumour models by comparison of genomic profiles. Nat Commun 2013;4:2126. 


\section{Cellular Physiology Cell Physiol Biochem 2016;38:1663-1680 \begin{tabular}{l|l} 
and Biochemistry Published online: May 03, 2016 & $\begin{array}{l}\text { DOI: } 2016 \text { The Author(s). Published by S. Karger AG, Basel } \\
\text { www.karger.com/cpb }\end{array}$
\end{tabular} \\ Brücher/Jamall: Hysteron and Proteron of the Somatic Mutation Theory}

6 Tomlinson IP, Novelli MR, Bodmer WF: The mutation rate and cancer. Proc Natl Acad Sci USA 1996;93:14800-14803.

7 Blattner WA: Human retroviruses: their role in cancer. Proc Assoc Am Physicians 1999;111:563-572.

8 Parkin DM: The global health burden of infection-associated cancers in the year 2002. Int J Cancer 2006;118:3030-3044.

9 Pisani P, Parkin DM, Munoz N, Ferlay J: Cancer and infection: estimates of the attributable fraction in 1990. Cancer Epidemiol Biomarkers Prev 1997;6:387-400.

10 Rosenfeld S: Are the somatic mutation and tissue organization field theories of carcinogenesis incompatible? Cancer Inform 2013;12:221-229.

11 Versteeg R: Cancer: tumours outside the mutation box. Nature 2014;506:438-439.

12 Mack SC, Witt H, Piro RM, Gu L, Zuyderduyn S, Stütz AM, Wang X, Gallo M, Garzia L, Zayne K, et al.: Epigenomic alterations define lethal CIMP-positive ependymomas of infancy. Nature 2014;506:445-450.

13 Parker M, Mohankumar KM, Punchihewa C, Weinlich R, Dalton JD, Li Y, Lee R, Tatevossian RG, Phoenix TN, Thiruvenkatam R, White E, Tang B, Orisme W, Gupta K, Rusch M, Chen X, Li Y, Nagahawhatte P, Hedlund E, Finkelstein D, Wu G, Shurtleff S, Easton J, Boggs K, Yergeau D, Vadodaria B, Mulder HL, Becksfort J, Gupta P, Huether R, Ma J, Song G, Gajjar A, Merchant T, Boop F, Smith AA, Ding L, Lu C, Ochoa K, Zhao D, Fulton RS, Fulton LL, Mardis ER, Wilson RK, Downing JR, Green DR, Zhang J, Ellison DW, Gilbertson RJ: C11orf95-RELA

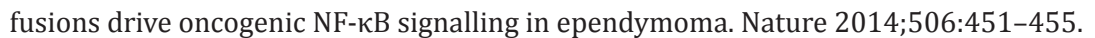

14 Veltman JA, Brunner HG: De novo mutations in human genetic disease. Nat Rev Genet 2012;13:565-575.

15 Molyneux SD, Waterhouse PD, Shelton D, Shao YW, Watling CM, Tang QL, Harris IS, Dickson BC, Tharmapalan P, Sandve GK, Zhang X, Bailey SD, Berman H, Wunder JS, Izsvák Z, Lupien M, Mak TW, Khokha R: Human somatic cell mutagenesis creates genetically tractable sarcomas. Nat Genet 2014;46:964-972.

16 Sitges-Serra A: Clinical guidelines at stake. J Epidemiol Community Health 2014;68:906-908.

17 Brücher BLDM, Jamal IS: Epistemology of the origin of cancer: a new paradigm. BMC Cancer 2014;14:1-8.

18 Brücher BLDM, Jamal IS: Cell-cell communication in the tumor microenvironment, carcinogenesis, and anticancer treatment. Cell Physiol Biochem 2014;34:213-243.

19 Boveri T: Zur Frage der Entstehung maligner Tumoren. Verlag von Gustav Fischer, Jena; 1914:29-32.

20 Bauer KH: Mutationstheorie der Geschwulst-Entstehung. Berlin: Julius Springer Verlag;1928.

21 Cobb M: 1953: when genes become "information". Cell 2013;153:503-506.

22 Watson JD, Crick FH: Molecular structure of nucleic acids; a structure for deoxyribose nucleic acid. Nature 1953;171:737-738.

23 Friedman M, Friedland GW: Medicine's 10 greatest discoveries. Yale University Press; 1998.

24 Chargaff E, Zamenhof S: Human desoxypentose nucleic acid: composition of human desoxypentose nucleic acid. J Biol Chem 1948;173:327.

25 Hershey JG, Chase M: Independent functions of viral protein and nucleic acid in growth of bacteriophage. J Gen Physiol 1952;36:39-56.

26 Franklin RE, Gosling R: Molecular Configuration in Sodium Thymonucleate. Nature 1953;171:740-741.

27 Kleppe K, Ohtsuka E, Kleppe R, Molineux I, Khorana HG: Studies on polynucleotides. XCVI. Repair replications of short synthetic DNA's as catalyzed by DNA polymerases. J Mol Biol 1971;56:341-361.

28 Mullis K, Faloona F, Scharf S, Saiki R, Horn G, Erlich H: Specific enzymatic amplification of DNA in vitro: the polymerase chain reaction. Cold Spring Harb Symp Quant Biol 1986;51:263-273.

29 Saiki RK, Gelfand DH, Stoffel S, Scharf SJ, Higuchi R, Horn GT, Mullis KB, Erlich HA: Primer-directed enzymatic amplification of DNA with a thermostable DNA polymerase. Science 1988;239:487-491.

30 Nordling CO: A new theory on the cancer-inducing mechanism. Br J Cancer 1953;7:68-72.

31 Ashley DJB: The two "hit" and multiple "hit" theories of carcinogenesis. Br J Cancer 1969;23:313-328.

32 Knudson AG: Mutation and cancer: statistical study of retinoblastoma. Proc Natl Acad Sci USA 1971;68:820-823.

33 Fearon ER, Vogelstein B: A genetic model for colorectal tumorigenesis. Cell 1990;61:759-767.

34 Tomasetti C, Marchionni L, Nowak MA, Parmigiani G, Vogelstein B: Only three driver gene mutations are required for the development of lung and colorectal cancers. Proc Natl Acad Sci USA 2015;112:118-123.

35 Roberts SA, Gordenin DA: Hypermutation in human cancer genomes: footprints and mechanisms. Nat Rev Cancer 2014;14:786-800.

36 Greenman C, Wooster R, Futreal PA, Stratton MR, Easton DF: Statistical analysis of pathogenicity of somatic mutations in cancer. Genetics 2006;173:2187-2198.

37 Sekeres MA, Bejanyan N: The Revolution of Myelodysplastic Syndromes. Ther Adv Hematol 2011;2:33-43. 


\section{Cellular Physiology Cell Physiol Biochem 2016;38:1663-1680 and Biochemistry Published online: May 03, $2016 \quad \begin{aligned} & \text { DOI: 10.1159/000443106 } \\ & \begin{array}{l}\text { C } 2016 \text { The Author(s). Published by S. Karger AG, Basel } \\ \text { www.karger.com/cpb }\end{array}\end{aligned}$ \\ Brücher/Jamall: Hysteron and Proteron of the Somatic Mutation Theory}

38 Lu L, Wang F, He L, Xue Y, Wang Y, Zhang H, Rong L, Wang M, Zhang Z, Fang Y, Miao H. Interaction Between IGF1 Polymorphisms and the Risk of Acute Lymphoblastic Leukemia in Chinese Children. Cell Physiol Biochem 2015;36:1346-1358.

39 Li X, Kong X, Jiang L, Ma T, Yan S, Yuan C, Yang Q. A genetic polymorphism (rs17251221) in the calciumsensing receptor is associated with breast cancer susceptibility and prognosis. Cell Physiol Biochem. 2014;33:165-172.

40 Wang Y, Zhou L, Chen J, Li J, He L, Wu P, Wang M, Tong N, Zhang Z, Fang Y. Association of the 3'UTR FOXO3a polymorphism rs4946936 with an increased risk of childhood acute lymphoblastic leukemia in a Chinese population. Cell Physiol Biochem. 2014;34:325-332.

41 Martin-Lorenzo A, Hauer J, Vicente-Dueñas C, Auer F, González-Herrero I, García-Ramírez I, Ginzel S, Thiele R, Constantinescu SN, Bartenhagen C, Dugas M, Gombert M, Schäfer D, Blanco O, Mayado A, Orfao A, Alonso-López D, Rivas Jde L, Cobaleda C, García-Cenador MB, García-Criado FJ, Sánchez-García I, Borkhardt A: Infection exposure is a causal factor in B-precursor acute lymphoblastic leukemia as a result of Pax5 inherited susceptibility. Cancer Discov 2015;5:1328-1343.

42 Greenman C, Stephens P, Smith R, Dalgliesh GL, Hunter C, Bignell G, Davies H, Teague J, Butler A, Stevens C, et al.: Patterns of somatic mutation in human cancer genome. Nature 2007;446:153-158.

43 Cohen N, Kravchenko-Balasha N, Klein S, Levitzki A: Heterogeneity of gene expression in murine squamous cell carcinoma development - the same tumor by different means. PLoS One 2013;8:e57748.

44 Druker BJ: Inhibition of the Bcr-Abl tyrosine kinase as a therapeutic strategy for CML. Oncogene 2002;21:8541-8546.

45 Yun M, Kim EO, Lee D, Kim JH, Kim J, Lee H, Lee J, Kim SH. Melatonin sensitizes H1975 non-small-cell lung cancer cells harboring a T790M-targeted epidermal growth factor receptor mutation to the tyrosine kinase inhibitor gefitinib. Cell Physiol Biochem 2014;34:865-872.

46 Tachibana M: Epigenetic regulation of mammalian sex determination. J Med Invest 2015;62:19-23.

47 Forsberg LA, Absher D, Dumanski JP: Non-heritable genetics of human disease: spotlight on post-zygotic genetic variation acquired during lifetime. J Med Genet 2013;50:1-10.

48 Jacobs KB, Yeager M, Zhou W, Wacholder S, Wang Z, Rodriguez-Santiago B, Hutchinson A, Deng X, Liu $\mathrm{C}$, Horner MJ, et al.: Detectable clonal mosaicism and its relationship to aging and cancer. Nat Genet 2012;44:651-658.

49 Bonduriansky R, Crean AJ, Day T: The implications of nongenetic inheritance for evolution in changing environments. Evol Appl 2012;5:192-201.

50 Colombo V, Pettigrove VJ, Golding LA, Hoffmann AA: Transgenerational effects of parental nutritional status on offspring development time, survival, fecundity, and sensitivity to zinc in Chironomus tepperi midges. Ecotoxicol Environ Saf 2014;110:1-7.

51 Enroth S, Johansson A, Enroth SB, Gyllensten U: Strong effects of genetic and lifestyle factors on biomarker variation and use of personalized cutoffs. Nat Commun 2014;5:4684.

52 Stelzner F. Botschaft des Genoms. Seiten 1296-1306 in: Bilanz zur Jahrtausendwende: 6.-10. April 1999. Hrsg. D. Rühland und W. Hartel. 116. Kongreß der Deutschen Gesellschaft für Chirurgie, Springer, Berlin, 1999.

53 Weinhold N, Jacobsen A, Schultz N, Sander C, Lee W: Genome-wide analysis of noncoding regulatory mutations in cancer. Nat Genet 2014;46:1160-1165.

54 ScienceNordic Interview by Kristian Sjøgren with the authors of Reference 27: http://sciencenordic.com/ mutations-noncoding-dna-also-cause-cancer 2014.

55 Kramczyk M, Emerson BM: p50-associated COX-2 extragenic RNA (PACER) activates COX-2 gene expression by occluding repressive NF- $\kappa$ B complexes. Elife 2014;3:e01776.

56 Stratigi K, Kaptsetaki M, Aivaliotis M, Town T, Flavell RA, Spilianakis CG: Spatial proximity of homologous alleles and long noncoding RNAs regulate a switch in allelic gene expression. Proc Natl Acad Sci USA 2015;112:E1577-1586.

57 Tan AS, Baty JW, Dong LF, Bezawork-Geleta A, Endaya B, Goodwin J, Bajzikova M, Kovarova J, Peterka M, Yan B, Pesdar EA, Sobol M, Filimonenko A, Stuart S, Vondrusova M, Kluckova K, Sachaphibulkij K, Rohlena J, Hozak P, Truksa J, Eccles D, Haupt LM, Griffiths LR, Neuzil J, Berridge MV: Mitochondrial Genome Acquisition Restores Respiratory Function and Tumorigenic Potential of Cancer Cells without Mitochondrial DNA. Cell Metab 2015;21:81-94.

58 Turner KH, Wessel AK, Palmer GC, Murray JL, Whiteley M: Essential genome of Pseudomonas aeruginosa in cystic fibrosis sputum. Proc Natl Acad Sci USA 2015;112:4110-4115. 


\section{Cellular Physiology Cell Physiol Biochem 2016;38:1663-1680

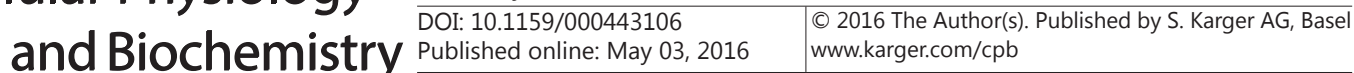 \\ Brücher/Jamall: Hysteron and Proteron of the Somatic Mutation Theory}

59 Sodergren E, Shen Y, Song X, Zhang L, Gibbs RA, Weinstock GM: Shedding genomic light on Aristotle's lantern. Dev Biol 2006;300:2-8.

60 Halemano K, Guo K, Heilman KJ, Barrett BS, Smith DS, Hasenkrug KJ, Santiago ML: Immunoglobulin somatic hypermutation by APOBEC3/Rfv3 during retroviral infection. Proc Natl Acad Sci USA 2014;111:7759-7764.

61 Loeb LA: A mutator phenotype in cancer. Cancer Res 2001;61:3230-3239.

62 Cervantes RB, Stringer JR, Shao C, Tischfield JA, Stambrook PJ: Embryonic stem cells and somatic cells differ in mutation frequency and type. Proc Natl Acad Sci USA 2002;99:3586-3590.

63 Lindahl T: Instability and decay of the primary structure of DNA. Nature 1993;362:709-715.

64 Ames BN, Gold LS, Wilett WC: The causes and prevention of cancer. Proc Natl Acad Sci USA 1995;92:52585265.

65 Wogan GN, Hecht SS, Felton JS, Conney AH, Loeb LA: Environmental and chemical carcinogenesis. Semin Cancer Biol 2004;14:473-486.

66 Touw IP, Erkeland SJ: Retroviral insertion mutagenesis in mice as a comparative oncogenomics tool to identify disease genes in human leukemia. Mol Ther 2007;15:13-19.

67 Holstege H, Pfeiffer W, Sie D, Hulsman M, Nicholas TJ, Lee CC, Ross T, Lin J, Miller MA, Ylstra B, MeijersHeijboer H, Brugman MH, Staal FJ, Holstege G, Reinders MJ, Harkins TT, Levy S, Sistermans EA: Somatic mutations found in the healthy blood compartment of a 115-yr-old woman demonstrate oligoclonal hematopoiesis. Genome Res 2014;24:733-742.

68 Kraft D, Rall M, Volcic M, Metzler E, Groo A, Stahl A, Bauer L, Nasonova E, Salles D, Taucher-Scholz G, Bönig H, Fournier C, Wiesmüller L: NF-кB-dependent DNA damage-signaling differentially regulates DNA double-strand break repair mechanisms in immature and mature human hematopoietic cells. Leukemia 2015;29:1543-1554.

69 Pikarsky E, Porat RM, Stein I, Abramovitch R, Amit S, Kasem S, Gutkovich-Pyest E, Urieli-Shoval S, Galun E, Ben-Neriah Y: NF-kB functions as a tumour promoter in inflammation-associated cancer. Nature 2004;431:461-466.

70 Oliveira AM, Ross JS, Fletcher JA: Tumor suppressor genes in breast cancer: the gatekeepers and the caretakers. Am J Clin Pathol 2005;124:16-28.

71 Chetram MA, Don-Salu-Hewage AS, Hinton CV: ROS enhances CXCR4-mediated functions through inactivation of PTEN in prostate cancer cells. Biochem Biophys Res Commun 2011;410:195-200.

72 Zhao S, Zhang Y, Sha K, Tang Q, Yang X, Yu C, Liu Z, Sun W, Cai L, Xu C, Cui S. KRAS (G12D) cooperates with AML1/ETO to initiate a mouse model mimicking human acute myeloid leukemia. Cell Physiol Biochem. 2014;33(1):78-87.

73 Wu C, Wang S, Xu C, Tyler A, Li X, Andersson C, Oji Y, Sugiyama H, Chen Y, Li A. WT1 enhances proliferation and impedes apoptosis in KRAS mutant NSCLC via targeting cMyc. Cell Physiol Biochem 2015;35:647-662.

74 LaFond RE: Cancer: The Outlaw Cell; in American Chemical Society, Washington, DC, 1978.

75 Conolly RB, Lutz WK: Nonmonotonic dose-response relationships: mechanistic basis, kinetic modeling, and implications for risk assessment. Toxicol Sci 2004;77:151-157.

76 Cleaver JE: DNA repair and replication in xeroderma pigmentosum and related disorders. Basic Life Sci 1986;39:425-438.

77 Milota M, Jones DL, Cleaver J, Jamall JS: Xeroderma pigmentosum family support group: Helping families and promoting clinical initiatives. DNA Repair (Amst) 2011;10:792-797.

78 Tomasetti C, Vogelstein B: Cancer etiology. Variation in cancer risk among tissues can be explained by the number of stem cell divisions. Science 2015;347:78-81.

79 Dürst M, Gissmann L, Ikenberg H, zur Hausen H: A papillomavirus DNA from a cervical carcinoma and its prevalence in cancer biopsy samples from different geographic regions. Proc Natl Acad Sci USA 1983;80:3812-3815.

80 Toki T, Oikawa N, Tase T, Satoh S, Wada Y, Yajima A: Immunohistochemical demonstration of papillomavirus antigen in cervical dysplasia and vulvar condyloma. Gynecol Obstet Invest 1986;22:97-101.

81 Walboomers JM, Jacobs MV, Manos MM, Bosch FX, Kummer JA, Shah KV, Snijders PJ, Peto J, Meijer CJ, Muñoz N: Human papillomavirus is a necessary cause of invasive cervical cancer worldwide. J Pathol 1999;189:12-19.

82 Woodworth CD, McMullin E, Iglesias M, Plowman GD: Interleukin 1 alpha and tumor necrosis factor alpha stimulate autocrine amphiregulin expression and proliferation of human papillomavirus-immortalized and carcinoma-derived cervical epithelial cells. Proc Natl Acad Sci USA 1995;92:2840-2844.

83 Jin YT, Tsai ST, Li C, Chang KC, Yan JJ, Chao WY, Eng HL, Chou TY, Wu TC, Su IJ: Prevalence of human papillomavirus in middle ear carcinoma associated with chronic otitis media. Am J Pathol 1997;150:1327-1333. 


\section{Cellular Physiology Cell Physiol Biochem 2016;38:1663-1680 \begin{tabular}{l|l} 
and Biochemistry & DOI: 10.1159/000443106 \\
Published online: May 03, 2016 & $\begin{array}{l}\text { (c) 2016 The Author(s). Published by S. Karger AG, Basel } \\
\text { www.karger.com/cpb }\end{array}$
\end{tabular} \\ Brücher/Jamall: Hysteron and Proteron of the Somatic Mutation Theory}

84 Senba M, Mori N, Wada A, Fujita S, Yasunami M, Irie S, Hayashi T, Igawa T, Kanetake H, Takahara O, Toriyama K: Human papillomavirus genotypes in penile cancers from Japanese patients and HPV-induced NF-кB activation. Oncol Lett 2010;1:267-272.

85 Boccardo E, Lepique AP, Villa LL: The role of inflammation in HPV carcinogenesis. Carcinogenesis 2010;31:1905-1912.

86 Moreas H, Tsiambas E, Lazaris AC, Nonni A, Karameris A, Metaxas GE, Armatas HE, Patsouris E: Impact of HPV detection in colorectal adenocarcinoma: HPV protein and chromogenic in situ hybridization analysis based on tissue microarrays. J Buon 2014;19:91-96.

87 Li YX, Zhang L, Simayi D, Zhang N, Tao L, Yang L, Zhao J, Chen YZ, Li F, Zhang WJ: Human Papillomavirus Infection Correlates with Inflammatory Stat3 Signaling Activity and IL-17 Level in Patients with Colorectal Cancer. PLoS One 2015;10:e0118391.

88 Li J, Ding J, Zhai K: Detection of human papillomavirus DNA in patients with breast tumor in china. PLoS One 2015;10:e0136050.

89 Mehryar MM, Li SY, Liu HW, Li F, Zhang F, Zhou YB, Zeng Y, Li JT: Prevalence of human papillomavirus in esophageal carcinoma in Tangshan, China. World J Gastroenterol 2015;21:2905-2911.

90 Gingery A, Bradaley EW, Pederson L, Ruan M, Horwood NJ, Oursler MJ: TGF-beta coordinately activates TAK1/MEK/AKT/NFkB and SMAD pathways to promote osteoclast survival. Exp Cell Res 2008;314:27252738.

91 Ogden SR, Wroblewski LE, Weydig C, Romero-Gallo J, O'Brien DP, Israel DA, Krishna US, Fingleton B, Reynolds AB, Wessler S, Peek RM Jr: p120 and Kaiso regulate Helicobacter pylori-induced expression of matrix metalloproteinase-7. Mol Biol Cell 2008;19:4110-4121.

92 Krakowiak MS, Noto JM, Piazuelo MB, Hardbower DM, Romero-Gallo J, Delgado A, Chaturvedi R, Correa P, Wilson KT, Peek RM Jr: Matrix metalloproteinase 7 restrains Helicobacter pylori-induced gastric inflammation and premalignant lesions in the stomach by altering macrophage polarization. Oncogene 2015;34:1865-1871.

93 Overall CM, Kleifeld O: Tumour microenvironment-opinion: validating matrix metalloproteinases as drug targets and anti-targets for cancer therapy. Nat Rev Cancer 2006;6:227-239.

94 Kessenbrock K, Plaks V, Werb Z: Matrix metalloproteinases: regulators of the tumor microenvironment. Cell 2010;141:52-67.

95 Wiercinska E, Naber HP, Paardali E, van der Pluijm G, van Dam H, ten Dijke P: The TGF- $\beta /$ Smad pathway induces breast cancer cell invasion through the up-regulation of matrix metalloproteinase 2 and 9 in a spheroid invasion model system. Breast Cancer Res Treat. 2011;128:657-666.

96 Mo N, Li ZQ, Li J, Cao JD: Curcumin inhibits TGF-B1-induced MMP-9 and invasion through ERK and Smad signaling in breast cancer MDA- MB-231 cells. Asian Pac J Cancer Prev 2012;13:5709-5714.

97 Egeblad M, Werb Z: New functions for the matrix metalloproteinases in cancer progression. Nat Rev Cancer 2002;2:161-174.

98 Overall CM, Lopez-Otin C: Strategies for MMP inhibition in cancer: innovations for the post-trial era. Nat Rev Cancer 2002;2:657-672.

99 Amour A, Knight CG, Webster A, Slocombe PM, Stephens PE, Knäuper V, Docherty AJ, Murphy G: The in vitro activity of ADAM-10 is inhibited by TIMP-1 and TIMP-3. FEBS Lett 2000;473:275-279.

100 Chirco R, Liu XW, Jung KK, Kim HR: Novel functions of TIMPs in cell signaling. Cancer Metastasis Rev 2006;25:99-113.

101 Elezkurtaj S, Kopitz C, Baker AH, Perez-Cantó A, Arlt MJ, Khokha R, Gansbacher B, Anton M, Brand K, Krüger A: Adenovirus mediated overexpression of tissue inhibitor of metalloproteinases- 1 in the liver: efficient protection against T-cell lymphoma and colon carcinoma metastasis. J. Gene Med 2004;6:1228-1237.

102 Brand K: Cancer gene therapy with tissue inhibitors of metalloproteinases (TIMPs). Curr Gene Ther 2002;2:255-271.

103 Gaide Chevronnay HP, Selvais C, Emonard H, Galant C, Marbaix E, Henriet P: Regulation of matrix metalloproteinases activity studied in human endometrium as a paradigm of cyclic tissue breakdown and regeneration. Biochim Biophys Acta 2012;1824:146-156.

104 Woessner JF, Taplin CJ: Purification and properties of a small latent matrix metalloproteinase of the rat uterus. J Biol Chem 1988;263:16918-16925.

105 Yokoyama Y, Grünebach F, Schmidt SM, Heine A, Häntschel M, Stevanovic S, Rammensee HG, Brossart P: Matrilysin (MMP-7) is a novel broadly expressed tumor antigen recognized by antigen-specific T cells. Clin Cancer Res 2008;14:5503-5511. 


\section{Cellular Physiology Cell Physiol Biochem 2016;38:1663-1680 \begin{tabular}{ll|l} 
and Biochemistry & DoI: 10.1159/000443106 & $\begin{array}{l}\text { C 2016 The Author(s). Published by S. Karger AG, Basel } \\
\text { www.karger.com/cpb }\end{array}$
\end{tabular} \\ Brücher/Jamall: Hysteron and Proteron of the Somatic Mutation Theory}

106 Guan PP, Yu X, Guo JJ, Wang Y, Wang T, Li JY, Konstantopoulos K, Wang ZY, Wang P: By activating matrix metalloproteinase-7, shear stress promotes chondrosarcoma cell motility, invasion and lung colonization. Oncotarget 2015;6:9140-9159.

107 Qasim BJ, Ali HH, Hussein AG: Immunohistochemical Expression of Matrix Metalloproteinase-7 in Human Colorectal Adenomas Using Specified Automated Cellular Image Analysis System. Saudi J Gastroenterol 2013;19:23-27.

108 Ahmed HOA, Haglund C, Virolainen S, Häyry V, Atula T, Kontio R, Salo T, Sorsa T, Hagström J: MMP-7, MMP8, and MMP-9 in oral and cutaneous squamous cell carcinomas. Oral Surg Oral Med Oral Pathol Oral Radiol 2015;119:459-467.

109 Yin Y, Grabowska Am, Clarke PA, Whelband E, Robinson K, Argent RH, Tobias A, Kumari R, Atherton JC, Watson SA: Helicobacter pylori potentiates epithelial:mesenchymal transition in gastric cancer: links to soluble HB-EGF, gastrin and matrix metalloproteinase-7. Gut 2010;59:1037-1045.

110 Chou YT, Wang H, Chen Y, Danielpour D, Yang YC: Cited2 modulates TGF-beta-mediated upregulation of MMP9. Oncogene 2006;25:5547-5560.

111 Sun L, Diamond ME, Ottaviano AJ, Joseph MJ, Ananthanarayan V, Munshi HG: Transforming growth factorbeta 1 promotes matrix metalloproteinase-9-mediated oral cancer invasion through snail expression. Mol. Cancer Res 2008;6:10-20.

112 Lemjabbar H, Gosset P, Lechapt-Zalcman E, Franco-Montoya ML, Wallaert B, Harf A, Lafuma C: Overexpression of alveolar macrophage gelatinase B (MMP-9) in patients with idiopathic pulmonary fibrosis: effects of steroid and immunosuppressive treatment. Am J Respir Cell Mol Biol 1999;20:903-913.

113 Chen P, Lu N, Ling Y, Chen Y, Hui H, Lu Z, Song X, Li Z, You Q, Guo Q: Inhibitory effects of wogonin on the invasion of human breast carcinoma cells by downregulating the expression and activity of matrix me talloproteinase-9. Toxicology 2011;282:122-128.

114 Hurst V, Goldberg PL, Minnear FL, Heimark RL, Vincent PA: Rearrangement of adherens junctions by transforming growth factorbeta1: role of contraction. Am J Physiol 1999;276:582-595.

115 Shinto O, Yashiro M, Kawajiri H, Shimizu K, Shimizu T, Miwa A, Hirakawa K: Inhibitory effect of a TGFbeta receptor type-I inhibitor, Ki26894, on invasiveness of scirrhous gastric cancer cells. Br J Cancer 2010;102:844-851.

116 Wang T, Zhang L, Shi C, Sun H, Wang J, Li R, Zou Z, Ran X, Su Y: TGF- $\beta$-induced miR-21 negatively regulates the antiproliferative activity but has no effect on EMT of TGF- $\beta$ in HaCaT cells. Int J Biochem Cell Biol 2012;44:366-376.

117 Xie L, Wu M, Lin H, Liu C, Yang H, Zhan J, Sun S: An increased ratio of serum miR-21 to miR-181a levels is associated with the early pathogenic process of chronic obstructive pulmonary disease in asymptomatic heavy smokers. Mol Biosyst 2014;10:1072-1081.

118 Mammoto T, Jiang E, Jiang A, Mammoto A: ECM structure and tissue stiffness control postnatal lung development through the LRP5-Tie2 signaling system. Am J Respir Mol Biol 2013;49:1009-1018.

119 Wong CC, Tse AP, Huang YP, Zhu YT, Chiu DK, Lai RK, Au SL, Kai AK, Lee JM, Wei LL, Tsang FH, Lo RC, Shi J, Zheng YP, Wong CM, Ng IO: Lysyl oxidase-like 2 is critical to tumor microenvironment and metastatic niche formation in hepatocellular carcinoma. Hepatology 2014;60:1645-1658.

120 Margadant C, Sonnenberg A: Integrin-TGF-beta crosstalk in fibrosis, cancer and wound healing. EMBO Rep 2010;11:97-105.

121 Lin YC, Jiang X, Nicolls MR: Reversal of Fibrosis in Chronic Rejection in Mouse Airways through Combined Relaxin and Lysyl Oxidase Inhibitor Therapy. Ann Am Thorac Soc 2015;1:75.

122 Xie J, Wang C, Huang DY, Zhang Y, Xu J, Kolesnikov SS, Sung KL, Zhao H: TGF-beta1 induces the different expressions of lysyl oxidases and matrixmetalloproteinases in anterior cruciate ligament and medial collateral ligament fibroblasts after mechanical injury. J Biomech 2013;46:890-898.

123 Pez F, Dayan F, Durivault J, Kaniewski B, Aimond G, Le Provost GS, Deux B, Clézardin P, Sommer P, Pouysségur J, Reynaud C: The HIF-1-inducible lysyloxidase activates HIF-1 via the Akt pathway in a positive regulation loop and synergizes with HIF-1 in promoting tumor cell growth. Cancer Res 2011;71:16471657.

124 Schlessinger K, Hall A: GSK-3beta sets Snail's pace. Nat Cell Biol 2004;6:913-915.

125 Peinado H, Quintanilla M, Cano A: Transforming growth factor beta-1induces snail transcription factor in epithelial cell lines: mechanisms forepithelial mesenchymal transitions. J Biol Chem 2003;278;2111321123.

126 Peinado H, Olmeda D, Cano A: Snail, Zeb and bHLH factors in tumourprogression: an alliance against the epithelial phenotype? Nat Rev Cancer 2007;7:415-428. 


\section{Cellular Physiology Cell Physiol Biochem 2016;38:1663-1680 \begin{tabular}{l|l} 
and Biochemistry Published online: May 03, 2016 & $\begin{array}{l}\text { C } 2016 \text { The Author(s). Published by S. Karger AG, Basel } \\
\text { www.karger.com/cpb }\end{array}$
\end{tabular} \\ Brücher/Jamall: Hysteron and Proteron of the Somatic Mutation Theory}

127 Noren NK, Liu BP, Burridge K, Kreft B: p120 catenin regulates the actin cytoskeleton via Rho family GTPases. J Cell Biol 2000;150:567-580.

128 Yilmaz M, Christofori G: Mechanisms of motility in metastasizing cells. Mol Cancer Res 2010;8:629-642.

129 Manov I, Hirsh M, Iancu TC, Malik A, Sotnichenko N, Band M, Avivi A, Shams I: Pronounced cancer resistance in a subterranean rodent, the blind mole-rat, Spalax: in vivo and in vitro evidence. BMC Biol 2013;11:1-17.

130 Tian X, Azpurua J, Hine C, Vaidya A, Myakishev-Rempel M, Ablaeva J, Mao Z, Nevo E, Gorbunova V, Seluanov A: High-molecular-mass hyaluronan mediates the cancer resistance of the naked mole rat. Nature 2013;499:346-349.

131 Yoshida K, Murata M, Yamaguchi T, Matsuzaki K: TGF- $\beta$ /Smad signaling during hepatic fibrocarcinogenesis. Int J Oncol 2014;45:1363-1371.

132 Barashi N, Weiss ID, Wald O, Wald H, Beider K, Abraham M, Klein S, Goldenberg D, Axelrod J, Pikarsky E, Abramovitch R, Zeira E, Galun E, Peled A: Inflammation-induced hepatocellular carcinoma is dependent on CCR5 in mice. Hepatology 2013; 58:1021-1030.

133 Anisowicz A, Bardwell L, Sager R: Constitutive overexpression of a growth-regulated gene in transformed Chinese hamster and human cells. Proc Natl Acad Sci USA 1987;84:7188-7192.

134 Clark-Lewis I, Dewald B, Geiser T, Moser B, Baggiolini M: Platelet factor 4 binds to interleukin 8 receptors and activates neutrophils when its $\mathrm{N}$ terminus is modified with Glu-Leu-Arg. Proc Natl Acad Sci USA 1993;90:3574-3577.

135 Zou A, Lambert D, Yeh H, Yasukawa K, Behbod F, Fan F, Cheng N: Elevated CXCL1 expression in breast cancer stroma predicts poor prognosis and is inversely associated with expression of TGF- $\beta$ signaling proteins. BMC Cancer 2014;14:1-16.

136 Wei ZW, Xia GK, Wu Y, Chen W, Xiang Z, Schwarz RE, Brekken RA, Awasthi N, He YL, Zhang CH: CXCL1 promotes tumor growth through VEGF pathway activation and is associated with inferior survival in gastric cancer. Cancer Lett 2015;359: 335-433.

137 Funaki S, Sawabata N, Nakagiri T, Shintani Y, Inoue M, Kadota Y, Minami M, Okumura M: Novel approach for detection of isolated tumor cells in pulmonary vein using negative selection method: morphological classification and clinical implications. Eur J Cardiothorac Surg 2011;40:322-327.

138 Nojiri T, Yamamoto K, Maeda H, Takeuchi Y, Funakoshi Y, Inoue M, Okumura M: Effect of low-dose human atrial natriuretic peptide on postoperative atrial fibrillation in patients undergoing pulmonary resection for lung cancer: a double-blind, placebo-controlled study. Thorac Cardiovasc Surg 2012;143:488-494.

139 Nojiri T, Inoue M, Yamamoto K, Maeda H, Takeuchi Y, Funakoshi Y, Okumura M: Effects of low-dose human atrial natriuretic peptide for preventing post-operative cardiopulmonary complications in elderly patients undergoing pulmonary resection for lung cancer. Eur J Cardiothorac Surg 2012;41: 1330-1334.

140 Nojiri T, Inoue M, Maeda H, Takeuchi Y, Sawabata N, Shintani Y, Yamamoto K, Okumura M: Low-dose human atrial natriuretic peptide for the prevention of postoperative cardiopulmonary complications in chronic obstructive pulmonary disease patients undergoing lung cancer surgery. Eur J Cardiothorac Surg 2013;44:98-103.

141 Calderone A, Thaik CM, Takahashi N, Chang DL, Colucci WS: Nitric oxide, atrial natriuretic peptide, and cyclic GMP inhibit the growth-promoting effects of norepinephrine in cardiac myocytes and fibroblasts. J Clin Invest 1998;101:812-818.

142 Kishimoto I, Tokudome T, Horio T, Garbers DL, Nakao K, Kangawa K: Natriuretic Peptide Signaling via Guanylyl Cyclase (GC)-A: An Endogenous Protective Mechanism of the Heart. Curr Cardiol Rev 2009;5:4551.

143 Nojiri T, Hosoda H, Tokudome T, Miura K, Ishikane S, Otani K, Kishimoto I, Shintani Y, Inoue M, Kimura T, Sawabata N, Minami M, Nakagiri T, Funaki S, Takeuchi Y, Maeda H, Kidoya H, Kiyonari H, Shioi G, Arai Y, Hasegawa T, Takakura N, Hori M, Ohno Y, Miyazato M, Mochizuki N, Okumura M, Kangawa K: Atrial natriuretic peptide prevents cancer metastasis through vascularendothelial cells. Proc Natl Acad Sci USA 2015;112: 4086-4091.

144 Thamavit W, Bhamarapravati N, Sahaphong S, Vajrasthira S, Angsubhakorn S: Effects of dimethylnitrosamine on induction of cholangiocarcinoma in Opisthorchis viverrini-infected Syrian golden hamsters. Cancer Res 1978;38:4634-4639.

145 Sonakul D, Koompirochana C, Chinda K, Stitnimakarn T: Hepatic carcinoma with opisthorchiasis. Southeast Asian J Trop Med Public Health 1978;9:215-219. 


\section{Cellular Physiology Cell Physiol Biochem 2016;38:1663-1680 and Biochemistry Published online: May 03, $2016 \quad \begin{aligned} & \text { DOI: 10.1159/000443106 } \\ & \begin{array}{l}\text { C 2016 The Author(s). Published by S. Karger AG, Basel } \\ \text { www.karger.com/cpb }\end{array}\end{aligned}$ \\ Brücher/Jamall: Hysteron and Proteron of the Somatic Mutation Theory}

146 Young ND, Nagarajan N, Lin SJ, Korhonen PK, Jex AR, Hall RS, Safavi-Hemami H, Kaewkong W, Bertrand D, Gao S, Seet Q, Wongkham S, Teh BT, Wongkham C, Intapan PM, Maleewong W, Yang X, Hu M, Wang Z, Hofmann A, Sternberg PW, Tan P, Wang J, Gasser RB: The Opisthorchis viverrini genome provides insights into life in the bile duct. Nat Commun 2014;5:4378.

147 Yang L, Kwon J, Popov Y, Gajdos GB, Ordog T, Brekken RA, Mukhopadhyay D, Schuppan D, Bi Y, Simonetto D, Shah VH: Vascular endothelial growth factor promotes fibrosis resolution and repair in mice. Gastroenterology 2014;146:1339-1350.

148 Ye Y, Zhou X, Li X, Tang Y, Sun Y, Fang J: Inhibition of epidermal growth factor receptor signaling prohibits metastasis of gastric cancer via downregulation of MMP7 and MMP13. Tumour Biol 2014;35:10891-10896.

149 Wong L, Hutson PR, Bushman W: Prostatic inflammation induces fibrosis in a mouse model of chronic bacterial infection. PLoS One 2014;9:e100770.

150 Engler AJ, Sen S, Sweeney HL, Discher DE: Matrix elasticity directs stem cell lineage specification. Cell 2006;126:677-689.

151 Guo J, Wang Y, Sachs F, Meng F: Actin stress in cell reprogramming. Proc Natl Acad Sci USA 2014;111:52525261.

152 Thiery JP, Acloque H, Huang RY, Nieto MA: Epithelial-mesenchymal transitions in development and disease. Cell 2009;139:871-890.

153 Mani SA, Guo W, Liao MJ, Eaton EN, Ayyanan A, Zhou AY, Brooks M, Reinhard F, Zhang CC, Shipitsin M, Campbell LL, Polyak K, Brisken C, Yang J, Weinberg RA: The epithelial-mesenchymal transition generates cells with properties of stem cells. Cell 2008;133:704-715.

154 Morel AP, Lievre M, Thomas C, Hinkal G, Ansieau S, Puisieux A: Generation of breast cancer stem cells through epithelial-mesenchymal transition. PLoS One 2008;3:e2888.

155 Kitamura J, Uemura M, Kurozumi M, Sonobe M, Manabe T, Hiai H, Date H, Kinoshita K: Chronic Lung Injury by Constitutive Expression of Activation-Induced Cytidine Deaminase Leads to Focal Mucous Cell Metaplasia and Cancer. PLoS One 2015;10:e0117986.

156 Viñals F, Pouysségur J: Transforming growth factor beta1 (TGF-beta1)promotes endothelial cell survival during in vitro angiogenesis via anautocrine mechanism implicating TGF-alpha signaling. Mol Cell Biol 2001;21:7218-7230.

157 Zeng Z, Sarbassov dos D, Samudio IJ, Yee KW, Munsell MF, Ellen Jackson C, Giles FJ, Sabatini DM, Andreeff M, Konopleva M: Rapamycin derivativesreduce mTORC2 signaling and inhibit AKT activation in AML. Blood 2007;109:3509-3512.

158 Thiem S, Pierce TP, Palmieri M, Putoczki TL, Buchert M, Preaudet A, Farid RO, Love C, Catimel B, Lei Z, Rozen S, Gopalakrishnan V, Schaper F, Hallek M, Boussioutas A, Tan P, Jarnicki A, Ernst M: mTORC1 inhibition restricts inflammation-associated gastrointestinal tumorigenesis in mice. J Clin Invest 2013;123: 767-781.

159 Park GB, Kim D, Kim YS, Kim S, Lee HK, Yang JW, Hur DY: The Epstein-Barr virus causes epithelialmesenchymal transition in human corneal epithelial cells via Syk/src and Akt/Erk signaling pathways. Invest Ophthalmol Vis Sci 2014;55:1770-1779.

160 Yang X, Li S, Li W, Chen J, Xiao X, Wang Y, Yan G, Chen L: Inactivation of lysyl oxidase by $\beta$-aminopropionitrile inhibits hypoxia-induced invasion and migration of cervical cancer cells. Oncol Rep 2013;29: 541-548.

161 Cigna N, Farrokhi Moshai E, Brayer S, Marchal-Somme J, Wémeau-Stervinou L, Fabre A, Mal H, Lesèche G, Dehoux M, Soler P, Crestani B, Mailleux AA: The hedgehog system machinery controls transforming growth factor- $\beta$-dependent myofibroblastic differentiation in humans: involvement in idiopathic pulmonary fibrosis. Am J Pathol 2012;181:2126-2137.

162 Islam SS, Mokhtari RB, Noman AS, Uddin M, Rahman MZ, Azadi MA, Zlotta A, van der Kwast T, Yeger H, Farhat WA: Sonic hedgehog (Shh) signaling promotes tumorigenicity and stemness via activation of epithelial-to-mesenchymal transition (EMT) in bladder cancer. Mol Carcinog 2015;Mar 1:3-11.

163 Bernardo C, Cunha MC, Santos JH, da Costa JM, Brindley PJ, Lopes C, Amado F, Ferreira R, Vitorino R, Santos LL: Insight into the molecular basis of Schistosoma haematobium-induced bladder cancer through urine proteomics. Tumour Biol 2016; DOI 10.1007/s13277-016-4997-y.

164 Hilton IB, D'lppolito AM, Vockley CM, Thakore PI, Crawford GE, Reddy TE, Gersbach CA: Epigenome editing by a CRISPR-Cas9-based acetyltransferase activates genes from promoters and enhancers. Nat Biotechnol 2015;33:510-517.

165 Fidler IJ, Kripke MK: The challenge of targeting metastasis. Cancer Metastasis Rev 2015;33:635-641. 